\title{
Right-Wing Populism and Gender: A Preliminary Cartography of an Emergent Field of Research
}

Gabriele Dietze and Julia Roth

Borrowing from Marx, we start our introductory remarks with the first words of the Communist Manifesto, 'A specter is haunting Europe': the specter of right-wing populism. This specter looks different everywhere, and it is also at home in other parts of the world, for example in the Americas, in India, in the Philippines. Some features appear in almost all places that are haunted by it: nativist ethnonationalism (Betz 2001), hostility towards elites (Canovan 1999), anti-pluralism (Müller 2017), or the opposition to immigration (Rydgren 2008). Other spectral attributes are context-specific: in Hungary, the government has closed down universities and abolished gender studies programs to impede 'foreign' influences; in Brazil, indigenous communities are expelled from their reclaimed land and excluded from political power; and the current US president wants to build a wall at the country's southern border as a protection against 'Mexican rapists.' Due to this oscillation of content and the lack of a consistent program, populism has been conceptualized as a 'thin centered ideology' (Mudde/Kaltwasser 2017: 6), to which diverse projects, convictions, and attitudes can cling and connect.

In any case, a common feature can be observed in all current versions of rightwing populism: an 'obsession with gender' and sexuality in different arenas. Populist actors conjure up the heteronormative nuclear family as the model of social organization, attack reproductive rights, question sex education, criticize a socalled 'gender ideology', reject same-sex marriage and seek to re-install biologically understood binary gender differences. Although this 'obsession with gender' has become an omnipresent mark in right-wing discourse, canonical research has rarely addressed this aspect, nor has gender been considered as one of the major attributes for the attractiveness of populism. Rather, the success of right-wing populism is usually attributed and reduced to economic, nationalistic, or culturalist reasons and motivations (Brubaker 2017; Gidron/Hall 2017; Norris/Inglehart 2019) and seen as unrelated to gender. The Oxford Handbook of Populism's entry on Gender still argues that gender is not central to right-wing populism; however, the connection between the two is described as, admittedly, 'largely understudied' (Abi-Hassan 2017: 1). 
By contrast, the authors of this collection assume that analyzing the increase and persuasiveness of right-wing populist tendencies is not possible without a gender perspective. Furthermore, we claim that an approach that encompasses gender as a social construction, as a social practice, as an axis of inequality, and as a link to the economic developments of neo-liberal globalization, poverty, and structural racism, is indispensable for understanding the political shift to the right. Consequently, an important dimension of right-wing populism research, for us, is the observation that populism is not only concerned with gender as an issue itself but also with gender as a meta-language for negotiating different conditions of inequality and power in the context of current struggles over hegemony, and over resources forged by neoliberalism.

Given that in the meantime numerous different modes of political objectives and utterances have by now been assembled under the umbrella term 'right-wing populism,' it seems productive to expand and elaborate on the concept. The essays assembled in this volume thus relate right-wing populism not only to parties, movements, or organizations, but also to media discourses, narratives, and forms of action. Therefore, the editors of this volume suggest to speak of a right-wing populist complex. Our notion of a 'complex' contains the older - but in many ways similar - phenomenon of right-wing extremism, as the chapter by Edma Ajanović, Stefanie Mayer, and Birgit Sauer shows. Furthermore, speaking of a right-wing populist complex also enables us to include religious fundamentalisms and formations of Catholicism as demonstrated by the contributions by Agnieszka Graff, Imke Schmincke, Cornelia Möser, and Roman Kuhar and Mojca Pajnik. Neither do we want to leave out certain fractions of mainstream feminism called 'Femonationalism' that partake in the stigmatization of male Muslim migrants - see the article by Niels Spierings - and refugees as a sexual threat to 'autochthonous' women (Hark/Villa 2017), discussed in the contributions by Julia Roth and Gabriele Dietze. And finally, it would be impossible to omit parts of the liberal bourgeois camp that have shifted from the middle ground to the right (Zick et. al. 2019) via their polemics against 'genderism' or and an alleged 'censorship.'

A strong anti-gender sentiment is also pervasive in populist regimes in Latin America and parts of Eastern Europe, where a 'gender ideology' is perceived as a form of 'ideological colonization' pushed by Western decadent liberal voices from the EU and NGOs, who impose their thus-perceived ill-advised emancipation programs on poorer countries (Korolczuk/Graff 2018). The latter strand of politics is addressed in the essays by Roman Kuhar and Mojca Pajnik, Agnieszka Graff, and Eva Kováts. Additionally, we observe an appropriation of identity politics and some sort of 'reverse anti-colonialism' (see Roth's contribution), according to which the victim's perspective is reclaimed by structurally hegemonic speakers. The latter is particularly obvious in the case of extreme right-wing masculinist actors on the in- 
ternet (such as online networks and producers), who are intensely hostile to gender issues, as Simon Strick's contribution illustrates.

The notion of a right-wing populist 'complex' allows us to connect different narratives relating to gender to various fields of inquiry. Thus, the chapters not only focus on actors or formations of the right-wing populist complex but also on the intersections of gender with other categories of social stratification such as race, ethnicity, class and religion. Hence, gender issues are structurally connected to globalization and the effects of gendered neoliberal transformations and encompass the question of pay and breadwinning as well as the international division of labor. The ways in which right-wing agents orchestrate the current shift to the right by the evocation of strong feelings provide a further important field of inquiry. Ruth Wodak, for instance, calls such affective strategies a Politics of Fear (Wodak 2015). Congruously, we add the crucial arenas of affect and emotion to the categories of gender, race, and class as the usual aspects of intersectional investigation. Because we think that sexuality is of major importance and plays a central role for mobilizing affects, we address this dimension separately (especially in the contributions by Patrick Wielowiejski, Möser, Schmincke, and Dietze).

\section{Fields of Inquiry - Emergent Research}

Although the field of inquiry 'right-wing populism and gender' is only just now beginning to emerge, we can draw on a number of pioneer publications: the special issue "Gender and the Populist Radical Right Politics" of the journal Patterns of Prejudice (Spierings et al. 2015) and the groundbreaking anthology Gender and Far Right Politics in Europe (Bitzan/Kötting 2017) as well as Birgit Sauer's fundamental essay "Gesellschaftstheoretische Überlegungen zum europäischen Rechtspopulismus. Zum Erklärungspotenzial der Kategorie Geschlecht” (Social-theoretical Thoughts on European Right-Wing Populism: On the Explanatory Potential of the Category Gender , in English) promotes a gender perspective for research on right-wing populism (Sauer 2017); Sauer pursues this perspective also in her contribution to this volume. In addition, special issues of gender-theoretical journals have lately been published on specific topics of right-wing populism. ${ }^{1}$

Feminist research has been dealing with women in the extreme right since early on, e.g. with women from the far-right in the KuKluxKlan (Blee 2008) or in 
a global perspective (Bacchetta/Power 2013), as well as in extremist parties (Amesberger/Halbmayr 2002; Birsl 2013; Bitzan 2017). We can further draw on a number of regional studies of particular national contexts on right-wing populism and gender, ${ }^{2}$ as well as on the Pan-European study on right-wing women, Triumph of the Women (Gutsche 2018a), by the German Friedrich Ebert Foundation. ${ }^{3}$ Recent research indicates that 'anti-genderism' is not only a major issue for right-wing populism (Hark/Villa 2015; Brandini-Aissis/Ogando 2018), but that it can be seen as a wide-spread phenomenon (Kuhar/Paternotte 2017; Gunnarsson Payne 2019), and that the fight against 'gender-ideology' is a potential tool to construct the totalitarian idea of 'people-as-one' (Salcel 2004: 96).

The emergent field of research on right-wing populism and gender has a strong affinity with the already established research on masculinity related to the subject (Norocel 2010; Erzeel/Rashkova 2017; Kimmel 2017; Mudde/Kaltwasser 2015). The chapters by Simon Schleusener, Sauer, and Strick pursue this dimension. Here, the relationship of patriarchal gender relations and capitalist socialization and subjectivization is central, as it had formerly been discussed in feminist research as 'capitalist patriarchy' (Eisenstein 1979), 'neopatriarchy,' (Campbell 2014) and in reflections on 'colonial patriarchy' (Lugones 2012).

The recent victory of capitalist market mechanisms in almost all areas of daily life has also resulted in a 'neoliberal equality' of well-educated women (see the articles by Schleusener and Dietze), which is one of the economic premises of 'femonationalisms' (Farris 2017) and neoliberal feminisms (Rottenberg 2014; Fraser 2016; Banet-Weiser et al. 2019). In contrast to such 'toxic feminisms' (Thelandersson 2014; Hark/Villa 2017), intersectional constellations of feminisms - that is, feminisms dedicated to the structural and inseparable entanglements of different axes of oppression and inequalities such as race, class, and gender - which practice a variety of forms of resistance against White mainstream feminisms, who often side with right-wingers in their anti-immigration stance. Intersectional feminists provide platforms against right-wing populism in the U.S. (Hess 2017; Draper/Mason-Deese 2018), in Latin America (Bidaseca/Loi 2017), and Europe (Wizorek 2014; Hark/Villa 2017), as the article by Roth illustrates.

Additionally, we want to emphasize the neoliberal revolution as a central backdrop of the right-wing populist complex and thus as one relevant field of research.

2 See for example from the Netherlands: de Lange; Mügge, 2015, 61-80; Scandinavia: Akkerman; Hagelund, 2007, 197-214; Meret; Siim, 2013, 78-96; Norocel, 2010, 170-183; Italy: Farris, 2017, and for France: Mayer, 2015, 391-414; Morgan, 2017, 887-906; Scrinzi, 2017, 87-101. version can be found online as pdf files: library.fes.de/pdf-files/dialog/14636.pdf; https://library.fes.de/pdf-files/dialog/14630.pdf. For an overview of German-language research on right-wing populism and gender, see Lang, 2018b, 147-161; Lang, 2018a; Fritzsche, 2018, 335346 and FE.IN, 2019. 
Related critical gender-sensitive research (Brown 2015; Duggan 2003, Fraser 2012) is therefore of great importance for any consideration of right-wing populism and gender. The economization and commodification of many areas of life, the erosion of the welfare state, the shift from solidarity to individual responsibility for oneself (the referral back to the family as agency of care, i.e. mostly to women), the associated global financial crises and the redistribution of social wealth, have an immense impact on the gender order (Lombardo et al. 2009), as the contributions of Schleusener and Sauer emphasize.

In particular, the gendered (or sexual) division of labor is gaining new importance - locally within families, and globally in the form of global care chains through which the care work of women in wealthier countries (who are integrated into the labor market) is 'outsourced' to women from mostly poorer regions. Meanwhile, the unequal division of labor between men and women at home remains largely untouched (Ehrenreich/Hochschild 2003). So far, approaches critical of neoliberalism with a gender focus (Dörre et al. 2006; Beier et al. 2018; Pühl/Sauer 2018) have hardly been combined with or applied to the right-wing populist complex (with the exception of Sauer). Conversely, existing studies of the right-wing populist complex that emphasize economic aspects mostly operate without a gender perspective (Schwander/Manow 2017; Rodrik 2018). We think that a gender perspective will shift the focus to one of the central fields of mobilization for the right and thus allow us to analyze the different effects that precarization has on male and female employment, on the gendered division of labor in families and on care work (Wichterich 2000).

Instead of addressing economic or political structures to explain current wrongs, right-wing populists claim that injustices and inequalities result from the success of liberal accomplishments that allegedly led to the rise of an undeserving elite whilst de-privileging the thus-perceived more deserving members of the White middle and lower classes, as the contributions by Spierings, Eszter Kováts, and Simon Strick show. Right-wing populists use this strategy to blame the achievements of emancipatory movements such as feminism or gay liberation for their followers' feeling of social insecurity.

Finally, a central dimension for the analysis of how the right-wing populist complex works is the examination of affects and emotions (Ahmed 2004; Wodak 2015; Rico/Guinjoan 2017). The fields of gender, family, and sexual politics are heavily loaded with emotions - fears, passions, impulses to protect - which right-wing populist actors trigger and transfer into affective patterns: in the 'crusades' against homosexual educators and the adoption of children by gay couples (see the contribution by Wielowiejski), for instance, the need to contain sexuality in the safe space of the heteronormative family is particularly evident. Likewise, early sex education is attacked with the same arguments, as Möser and Schmincke explain for the French and German campaigns, such as Manif pour tous or Demo für alle, 
respectively. As Sauer's contribution shows, emotional patterns beyond sexuality lead to new forms of 'affective citizenship.' Patterns such as 'concern' - think of the many 'concerned citizens' (besorgte Bürger, in German) in right-wing populist propaganda - or anger, counting as male virtues that are cultivated as legitimate 'political feelings' in right-wing populism. Kovát's contribution illustrates how such patterns work in the Hungarian context, where feelings of hatred towards allegedly dangerous foreigners and feminists are kindled and supported by the government.

Right-wing populists often manage to mobilize particular features of shared affects. The anthropologist Arlie Hochschild has recently described the attractiveness of Trumpism for women at Trump's election rallies as the chance for 'feeling politically together' (Hochschild 2016). In his contribution, Strick examines the workings of masculinist 'affective communities' on the Internet. These observations seemingly feed Chantal Mouffe's claim, made at the turn of the millennium, of the right dominating the affective realm at the time, since the left did not seem to have alternative imaginaries to offer (Mouffe 2000). Fifteen to twenty years later there are indicators of a change. By uniting precarious and diverse bodies in the streets, new feminist movements such as the 'Black Protest' in Poland, NiUnaMenos in Argentina, the international Women's Strike of March 8, or the Women's Marches in the U.S. seemingly provide a powerful emotional counterforce to the right-wing populist trend (Butler 2016; Roth 2020a). By evoking shared feelings of 'embodied intersectionality,' these movements promote and perform an inclusive form of solidarity as opposed to the exclusive notion that is grounded in the imaginary of the national supremacy predominating the right-wing populist complex (see the contributions by Graff and Roth).

\section{Racialized Sexual Politics - Old and New Modernities}

Right-wing 'obsession with gender' is most closely linked to a promotion of the 'ethno-sexist' (Dietze 2016) exclusion of racialized Others who are constructed as dangerous to the reproduction of the White national body. The narrative of migrants as a sexual threat, as was brought forward by the 'cultural panic' surrounding the harassments at New Year's Eve 2015/16 in Cologne, Germany, and through Trump's dictum of the 'Mexican rapist intruder,' provides striking examples. Another narrative constructs the fear of 'autochthonous' citizens being 'outnumbered' by the fertility of non-autochthonous 'invaders,' through which right-wing actors launch a selective pro-natalism (Schultz 2015) targeting particularly White women. Feminists, especially activists in pro-choice campaigns, are regarded as enemies in this respect. Recent transnational efforts to abolish or limit reproductive rights are closely related to this narrative (Gökarıksel et al. 2019), as Graff's contribution on the struggle of the feminist 'Black Protest' in Poland shows. Beyond the obvious 
control of women's bodies, the cut into reproductive rights is aimed particularly at demographic policies (Schultz 2015; Fixmer-Oraiz 2019) in order to promote a 'New Maternalism' (Mezey/Pillard 2011), as Dietze argues in her contribution.

In consequence, right-wing populists question, oppose, and ambitiously fight feminists, non-traditional ways of life, and gender studies, perceiving them as obstacles to demographic goals. They represent emancipatory projects as a version of an 'old modernity' that terrorizes the 'people' with their sexualized ideas and models of the 'normalcy' of homosexuality and the alleged existence of more than two genders. Conversely, almost all formations of the right-wing populist complex claim to stand for a 'new' and 'other' modernity. Accordingly, in their contribution, Ajanović, Mayer and Sauer speak of a 'limited modernity' and Spierings of neo-traditionalization. This modern window dressing re-arranges traditional 'values' in a new narrative. Elaborating on Bauman's concept of 'Retrotopia' (Bauman 2017), for such visions of the future based on an idealized past, Schleusener coins the notion 'retrotopian desire' in his contribution. Related right-wing populist or conservative new/old brands of politics encase traditional forms of social life such as the church, the homeland (Heimat, in German), the 'people,' and the heteronormative family with an aura of a counterrevolution aiming at reoccupying lost territory. As a consequence, they fight an elite perceived as sexually licentious, unprincipled (secular), cosmopolitan (without homeland) and narcissistic-individualistic (singles, promoters of homosexuality). Right-wing populist logics are built on the construction of an inner enemy (the 'corrupt' elite, feminists, LGBTQI activists, political correctness etc.) and an outer enemy (immigrants as competitors for jobs and welfare and as threat to the national culture and sexual liberty of White women, 'gender ideology' as transnational menace to families, children, and the reproduction of the nation). These peculiarities stage gender as a central arena for polarizations, and thus for the working of right-wing populism in general.

Simultaneously, but not contradictorily, a kind of 'strategic progressivism' in sexual matters can be observed in right-wing populism in Europe and the United States. This pattern is expressed in the form of a 'sexual nationalism' (Mepschen/Duyvendak 2012) or 'sexual exceptionalism' (Bracke 2011; Puar 2011; Dietze 2019), which projects sexism onto racalized Others constructed as intruders and sexual threats to the nation and the national culture. Following this pattern, rightwing populists can claim to defend the sexual freedom of women (and sometimes of gays and LGBT persons) against the sexism and homophobia of Others. In Germany, gay activists within the AfD defend (non-queer) homosexuality as a stronghold against gender-ambivalence, due to the assumed implied preference for one clear-cut gender (see Wielowiejski's contribution). Following this pattern, women from the Global North need to be protected from sexual harassment by racialized or ethnicized men - in the European context that means mostly young Muslim migrants. Western women can thereby draw an 'occidental dividend' (Di- 
etze 2010: 100) based on the supposed superiority of occidental sexual and gender regimes in contrast to backwards 'oriental' gender regimes. Thereby they can simultaneously be presented as already 'fully emancipated' and as having achieved sexual self-determination. Equality politics and gender mainstreaming thus appear as not only unnecessary but also as harmful, because they undermine the selfconfidence and agency of 'autochthonous' women and condemn them to an eternal victim position. The underlying contradictions - such as pro traditional family and for the defense of the sexual liberty of women and gays - a phenomenon Gutsche (2018) calls "pro women, against feminists," are foundational for the gendered logics of right-wing populists and represent "calculated ambivalences" aimed to reach different fractions of a possible electorate (Reisigl 2020).

\section{Gender as Meta-Language for Political Maneuvering}

Right-wing populists not only raise questions of gender because they touch deep inner beliefs about what is considered appropriate by considerable parts of the population who feel overrun by 'progressively contaminated' public discourse, but also because it is a tool with which alliances can be forged. A study by the Friedrich Ebert Foundation on European anti-gender mobilization in 2015 is aptly titled Gender as Symbolic Glue (Kováts/Pōim 2015). In France, a campaign against gendersensitive sex education and adoption rights for homosexuals united conservative Catholics, right-wing populists, and supporters of a private school system. There was a large turn-out by these groups to protests, and the campaign was able to recruit voters in favor of the Front National for the next election. Gender could be instrumentalized as a tool of coalition building, not only on national grounds but in international realms as well: Brazil's newly elected President Jair Bolsonaro bonded with US President Donald Trump during his inaugural visit in March 2019 over being united in their 'fight against gender ideology' and 'political correctness' (Wempel 2018). In Hungary, gender mainstreaming introduced by the EU was perceived as 'Western imperialism' aimed at destroying the cultural identity of a small country. In a similar vein, Pope Francis described 'gender ideology' as "ideological colonization" used by international institutions to push pressure on poorer countries by forcing their dangerous concepts on them, thus uniting a broad spectrum of actors ranging from conservative Catholics to Evangelicals, Muslims, and orthodox Jews who consider themselves to be victims of this 'ideology' (Case 2019). After several priests in Poland had been accused of molesting children over a long period of time - incidents which the clerical authorities had known about but decided not to persecute -, the Catholic Church chose to decry the harmfulness of the gender category in December 2013 with a pastoral letter against the "gender ideology" instead of responding to the allegations against their priests. 
Each of these examples shows that gender issues are suitable to fuel the struggle over 'cultural hegemony' in a Gramscian sense. Following Gramsci, launching certain ideas can bring about a slight shift in public discourse (senso communo), which is structurally capable of leading to a change in the entire perception of 'reality' The French right-wing intellectual Alain de Benoist took up this concept in order to develop strategies to push the senso communo more into the political camp of the right-wingers. In order to set this in motion, following Benoist, so-called meta-politics is needed, i.e. the political propaganda should not be oriented towards parties, elections, and parliaments, but should work with everyday topics that are strongly interconnected with feelings. In this context, art forms like music, such as right-wing rock and folk festivals, are strategic fields through which cultural hegemony can be promoted meta-politically. The right-wing extremist campaign ' $1 \%$ for Germany' is based on the conviction that if small minorities can be seduced and convinced by right-wing extremist ideas, the concept can be transferred to society as a whole and thereby create cultural hegemony via metapolitics.

All these political maneuverings considered, one question is still in need of explanation: Why of all things is the category 'gender' so useful for meta-politics? The editors of this volume agree with Sauer's analysis (2017) that gender relations, or more precisely the relation of two sexes as an imagined binary, are still regarded as immutable natural facts - regardless of the emancipation movements of recent decades. Populists do not tire of invoking the allegedly inescapable 'biological' difference of the sexes, which are understood as antagonistic and complementary. This assertion naturalizes heteronormative couplings and reifies the related hierarchy between men and women. Assuming two (and only two) sexes as binary and hierarchically arranged is the essential category of order per se. The right-wing struggle against gender is thus always also a struggle against the dissolution of 'natural' orders, indeed a challenge of order in general (see the contribution of Spierings on 'order society'). In this respect, the sexes cannot be socially constructed in any case, because they would then be malleable and would thereby not only lose their function to describe and guarantee a hierarchical order, but would also question male domination, which is still one of the major motivations for problematizing 'gender' in the first place.

By bringing different actors and fields of investigation together, this collected volume seeks to combine case studies and theoretical considerations on a right-wing populist complex and gender with an intersectional perspective that integrates 'race'/ethnicity/religion, class/neoliberalism/milieu, and affect/emotion/feelings into its analysis, thereby identifying sexual politics as one of the main arenas of 
contention. Moreover, the collection of contributions seeks to demonstrate that the category of gender is not only crucial not just for analyzing the shift to the right, analyzing its programmatic contents and objectives, and understanding its attractiveness. Employing gender in right-wing rhetoric can also mean using the category as a tool for coalition building, a right-wing critique of globalization and for ethnonationalism, and as a vehicle for gaining cultural hegemony. Taken together, all these elements are constitutive for the success and impact of the rightwing populist complex in different and context-related forms and they cannot be understood without implementing a systematic gender lens.

As we have seen, right-wing populist actors have moved the struggle over hegemony center stage, and gender serves them as a meta-language, as an "affective bridge" (Dietze 2019) and as a central arena for that matter. Judith Butler recently described the right-wing obsession with gender as a replacement, condensation and abbreviation of cultural anxiety (Butler 2020). However, this struggle is far from being decided. Because of the strong entanglements of the right-wing populist complex with other forces of inequality and injustice and its spectral presence in so many areas, the disruption of these articulations requires many different paths. The numerous feminist protests emerging recently - that are the focus of the last part of this volume (see chapters of Roth and Graff) - have indicated that the fight concerning the contestations and withdrawals of rights takes place on the streets. These movements demonstrate that it continues to be worthwhile to intervene in public discourse at the discursive level in order to ward off the right-wing grasp for cultural hegemony, albeit without zeal and anger but with patience and emphasis. The current protests also show that the manipulations via exclusionary affects such as fear and wrath can be countered with inclusive affects like solidarity and empathy. The right-wing populist offer part of 'the people-as-one' can be denied on grounds of a preference for a 'people-as-multiple' (Gunnarsson-Payne 2019: 7) and nonconformist notions of diversity. In this current state of affairs, to quote Toni Morrison, who passed away while these last lines were in the making, "All necks are on the line." (Morrison 1989).

\section{Bibliography}

Abi-Hassan, Sahar (2017): "Populism and Gender." In: Cristóbal Rovira Kaltwasser/Paul A. Taggart/Paulina Ochoa Espejo et al. (eds.), The Oxford Handbook of Populism. Oxford: Oxford University Press, pp. 2-22.

Ahmed, Sara (2004): “Collective Feelings." In: Theory, Culture, and Society 21 (2), pp. 25-42.

Amesberger, Helga/Halbmayr, Brigitte (eds.) (2002): Rechtsextreme Parteien, eine Mögliche Heimat für Frauen?. Opladen: Leske \& Budrich. 
Akkerman, Tjitske/Hagelund, Anniken (2007): “Women and Children First!' AntiImmigration Parties and Gender in Norway and the Netherlands." In: Patterns of Prejudice 41 (2), pp. 197-214.

Bacchetta, Paola/Power, Margaret (2013): Right-Wing Women: From Conservatives to Extremists Around the World. New York: Routledge.

Banet-Weiser, Sarah/Gill, Rosalind/Rottenberg, Catherine (2019): Postfeminism, Popular Feminism and Neoliberal Feminism? Sarah Banet-Weiser, Rosalind Gill and Catherine Rottenberg in Conversation. Online: journals.sagepub.com/doi/full/10.1177/1464700119842555, 03.10.2019.

Bauman, Zygmunt (2017): Retrotopia. Cambridge: Polity Press.

Beier, Friederike/Haller, Lisa Yashodhara/Haneberg, Lea (eds.) (2018): Materializing Feminism. Positionierung zur Ökonomie, Staat und Identität. Münster: Unrast.

Betz, Hans-Georg (2001): "Rechtspopulismus und Ethnonationalismus. Erfolgsbedingungen und Zukunftschancen." In: Klaus Leggewie/Richard Münch (eds.), Politik im 21. Jahrhundert. Frankfurt a. M.: Suhrkamp, pp. 122-138.

Bidaseca, Karina/Loi, Yanina (2017): "8M: Ni una Menos: Paro Internacional de Mujeres.” In: Milena Caserola (ed.), 8M: Ni una Menos: Vivos nos Queremos. Buenos Aires:, pp. 9-14.

Birsl, Ursula (2013): Rechtsextremismus: Weiblich - Männlich? Eine Fallstudie zu Geschlechtsspezifischen Lebensverläufen, Handlungsspielräumen und Orientierungsweisen. Wiesbaden: VSA.

Bitzan, Renate/Köttig, Michaela/Petö, Andrea (2017): Gender and Far Right Politics in Europe. London: Palgrave.

Blee, Kathleen M. (2008): Women of the Klan: Racism and Gender in the 1920s. Berkeley: University of California Press.

Bracke, Sarah (2011): "Subjects of Debate. Secular and Sexual Exceptionalism and Muslim Women in the Netherlands." In: Feminist Review 98 (1), pp. 28-46.

Brandini-Aissis, Mariana/Ogando, Ana C. (2018): Gender Ideology and the Brazilian Elections. Online: www.publicseminar.org/2018/11/gender-ideology-andthe-brazilian-elections/, 21.06.2019.

Brubaker, Roger (2017): "Between Nationalism and Civilizationism: The European Populist Moment in Comparative Perspective." In: Ethnic and Racial Studies 40 (8), pp. 1191-1226.

Butler, Judith (2020): “Gender, whose Fantasy." Keynote at the $10^{\text {th }}$ anniversary of the Fachgruppe Gender-Studies at the Technische Universität, Berlin 31.01.2020.

Campbell, Beatrix (2014): Neoliberal Neopatriarchy: The Case for Gender Revolution. Online: www.opendemocracy.net/en/5050/neoliberal-neopatriarchycase-for-gender-revolution/, 27.07.2019. 
Canovan, Margaret (1999): "Trust the People! Populism and the Two Faces of Democracy." In: Political Studies 47 (1), pp. 2-16.

Case, Mary Ann (2019): "Trans Formations in the Vatican's War on 'Gender Ideology'.” In: Signs: Journal of Women in Culture and Society 44 (3), pp. 639-664.

de Lange, Sarah L./Mügge, Liza M. (2015): "Gender and Right-Wing Populism in the Low Countries. Ideological Variations across Parties and Time.” In: Patterns of Prejudice 49 (1-2), pp. 61-80.

Dietze, Gabriele (2010): “Occidentalism, European Identity, and Sexual Politics." In: Hauke Brunkhorst/Gerd Groezinger (eds.), The Study of Europe. Baden Baden: Nomos, pp. 87-116.

Dietze, Gabriele (2016): “Ethnosexismus.” In: Movements 2, pp. 157-165.

Dietze, Gabriele (2019): Sexueller Exzeptionalismus. Überlegenheitsnarrative in Immigrationsabwehr und Rechtspopulismus. Bielefeld: transcript.

Dörre, Klaus/Kraemer, Klaus/Speidel, Frederic (2006): "The Increasing Precariousness of the Employment Society: Driving Force for a New Right Wing Populism?" In: International Journal of Action Research 2 (1), pp. 98-128.

Draper, Susana/Mason-Deese, Liz (2018): "Strike as Process: Building the Poetics of a New Feminism." In: South Atlantic Quarterly 117 (3), pp. 682-691.

Ehrenreich, Barbara/Hochschild, Arlie Russell/Kay, Shara (2003): Global Woman: Nannies, Maids, and Sex Workers in the New Economy. London: McMillan.

Eisenstein, Zillah R. (ed.) (1979): Capitalist Patriarchy and the Case for Socialist Feminism. New York: Monthly Review Press.

Erzeel, Silvia/Rashkova, Ekaterina R. (2017): "Still Men's Parties? Gender and the Radical Right in Comparative Perspective." In: West European Politics 40 (4), pp. 812-820.

Farris, Sara R. (2017): In the Name of Women's Rights: The Rise of Femonationalism. Durham: Duke University Press.

FE.IN, Autor*innen Kollektiv (2019): Frauen*rechte und Frauen*hass. Antifeminismus und die Ethnisierung von Gewalt. Berlin: Verbrecher Verlag.

Fixmer-Oraiz, Natalie (2019): Homeland Maternity. Chicago: Illinois University Press.

Fraser, Nancy (2016): "Progressive Neoliberalism versus Reactionary Populism: A Choice that Feminists Should Refuse." In: NORA-Nordic Journal of Feminist and Gender Research 24 (4), pp. 281-284.

Gidron, Noam/Hall, Peter A. (2017): "The Politics of Social Status: Economic and Cultural Roots of the Populist Right." In: The British Journal of Sociology 68, pp. 57-84.

Gunnarson-Payne, Jenny (2019): "Challenging ‘Gender-Ideology’ (Anti)Gender Politics in Europe's Populist Moment.” In: The New Pretender (February 10), pp. 1-10. 
Gutsche, Elisa (ed.) (2018a): Triumph of Women. The Female Face of the Populist and Far Right in Europe. Berlin: Friedrich Ebert Stiftung.

Gutsche, Elisa (ed.) (2018b): Triumph der Frauen. Das Weibliche Gesicht der der Populistischen und Extremen Rechten in Europa. Berlin: Friedrich Ebert Stiftung.

Hark, Sabine/Villa, Paula-Irene (eds.) (2015): Anti-Genderismus. Sexualität und Geschlecht als Schauplätze Aktueller Politischer Auseinandersetzungen. Bielefeld: transcript.

Hark, Sabine/Villa, Paula-Irene (2017): Unterscheiden und Herrschen. Ein Essay zu den Ambivalenten Verflechtungen von Rassismus, Sexismus und Feminismus in der Gegenwart. Bielefeld: transcript.

Hess, Amanda (2017): How a Fractious Women's Movement Came to Lead the Left. Online: www.nytimes.com/2017/02/07/magazine/how-a-fractiouswomens-movement-came-to-lead-the-left.html, 05.05.2019.

Hochschild, Arlie Russell (2016): Strangers in Their Own Land: Anger and Mourning on the American Right. New York: The New Press.

Kimmel, Michael (2017): Angry White Men: American Masculinity at the End of an Era. London: Hachette.

Korolczuk, Elżbieta/Graff, Agnieszka (2018): “Gender as 'Ebola from Brussels': The Anticolonial Frame and the Rise of Illiberal Populism." In: Signs: Journal of Women in Culture and Society 43 (4), pp. 797-821.

Kovàts, Eszter/Pōim, Maari (eds.): Parties in the Anti-Gender Mobilizations in Europe. Berlin: Friedrich Ebert Stiftung.

Kuhar, Roman/Paternotte, David (2017): Anti-Gender Campaigns in Europe: Mobilizing against Equality. London: Rowman \& Littlefield.

Lang, Juliane (2018a): Feminismus von Rechts. Neue Rechte Politiken zwischen Forderung nach Frauenrechten und Offenem Antifeminismus. Online: dekonstrukt.org/impulse-3-feminismus-von-rechts-erschienen, 10.03.2019.

Lang, Juliane (2018b): “Alles beim Alten?! Überlegungen zu Anhaltenden Relevanz von Geschlechterpolitik in der Extremen Rechten.” In: Alexander Häusler/Helmut Kellershohn (eds.), Das Gesicht des Völkischen Populismus. Neue Herausforderungen für eine Kritische Rechtsextremismusforschung. Münster: Unrast, pp. 147-161.

Lang, Juliane/Fritzsche, Christopher (2018): "Backlash, Neoreaktionäre Politiken oder Antifeminismus. Forschende Perspektiven auf Aktuelle Debatten um Geschlecht." In: Feministische Studien (2), pp. 335-346.

Lombardo, Emanuela/Meier, Petra/Verloo, Mieke (2009): The Discursive Politics of Gender Equality: Stretching, Bending and Policy-Making. New York: Routledge. Lugones, Maria (2012): “The Coloniality of Gender." In: Walter Mignolo/Arturo Escobar (eds.), Globalization and the Decolonial Option. New York: Routledge, pp. 369-391. 
Mayer, Nonna (2015): “The Closing of the Radical Right Gender Gap in France?" In: French Politics 13 (4), pp. 391-414.

Mepschen, Paul/Duyvendak, Jan Willem (2012): "European Sexual Nationalisms. The Culturalization of Citizenship and the Sexual Politics of Belonging and Exclusion." In: Perspectives on Europe 42 (1), pp. 70-76.

Meret, Susi/Siim, Birte (2013): "Gender, Populism and Politics of Belonging. Discourses of Right-Wing Populist Parties in Denmark, Norway and Austria." In: Birte Siim/Monica Mokre (eds.), Negotiating Gender and Diversity in an Emergent European Public Sphere. London: Palgrave, pp. 78-96.

Mezey, Naomi/Pillard, Cornelia T. (2012): Against the New Maternalism. In: Michigan Journal of Gender \& Law (18), pp. 229-296.

Morgan, Kimberly J. (2017): "Gender, Right-Wing Populism, and Immigrant Integration Policies in France, 1989-2012.” In: West European Politics 40 (4), pp. 887-906.

Morrison, Toni (1989): "Unspeakable Things Unspoken: The Afro-American Presence in American Literature." In: Michigan Quarterly Review 28, pp. 1-34.

Mouffe, Chantal (2000): "Politics and Passions: The Stakes of Democracy." In: Ethical Perspectives 7 (2-3), pp. 146-150.

Mudde, Cas/Kaltwasser, Cristóbal Rovira (2015): "Vox Populi or Vox Masculini? Populism and Gender in Northern Europe and South America." In: Patterns of Prejudice 49 (1-2), pp. 16-36.

Mudde, Cas/Kaltwasser, Cristóbal Rovira (2017): Populism: A Very Short Introduction. Oxford: Oxford University Press.

Müller, Jan-Werner (2017): What Is Populism? London: Penguin.

Norocel, Ov Cristian (2010): "Constructing Radical Right Populist Resistance: Metaphors of Heterosexist Masculinities and the Family Question in Sweden." In: Norma 5 (2), pp. 170-183.

Norris, Pippa/Inglehart, Ronald (2019): Cultural Backlash. Trump, Brexit and the Rise of Authoritarian Populism. Online: www.un.org/development/desa/dspd/wp-content/uploads/sites/, 05.04.2019.

Puar, Jasbir (2011): "Abu Ghraib and U.S. Sexual Exceptionalism." In: Works and Days 29, pp. 115-142.

Pühl, Katharina/Sauer, Birgit (2018): Kapitalismuskritische Gesellschaftsanalyse: Queerfeministische Positionen. Münster: Unrast.

Reisigl, Martin (2020): "Mit zweierlei Maß gemessen, kalkulierte Ambivalenz in rechtspopulistischen Repräsentationen von Geschlechterverhältnissen." Forthcoming in: Zeitschrift für Literatur und Linguistik, spring.

Rodrik, Dani (2018): "Populism and the Economics of Globalization." In: Journal of International Business Policy 1 (1-2), pp. 12-33.

Roth, Julia (2020a): Can Feminism Trump Populism? Right-Wing Trends and Intersectional Contestations in the Americas. Trier WVT/Bilingual Press (in print). 
Roth, Julia (2020b): ¿Puede el Feminismo Vencer al Populismo? Tendencias de Derecha y Disputas Interseccionales en las Américas. Bielefeld: Kipu Verlag. Rottenberg, Catherine (2014): “The Rise of Neoliberal Feminism." In: Cultural Studies 28 (3), pp. 418-437.

Rydgren, Jens (2008): "Immigration Sceptics, Xenophobes or Racists? Radical Right-Wing Voting in Six West European Countries." In: European Journal of Political Research 47 (6), pp. 737-765.

Salecl, Renata (2004) [1994]: The Spoils of Freedom: Psychoanalysis, Feminism and Ideology after the Fall of Socialism. London: Routledge.

Sauer, Birgit (2017): "Gesellschaftstheoretische Überlegungen zum Europäischen Rechtspopulismus. Zum Erklärungspotenzial der Kategorie Geschlecht.” In: PVS Politische Vierteljahresschrift 58 (1), pp. 3-22.

Schultz, Susanne (2015): "Reproducing the Nation: The New German Population Policy and the Concept of Demographization." In: Distinktion: Scandinavian Journal of Social Theory 16 (3), pp. 337-361.

Schwander, Hanna/Manow, Philip (2017): "It's Not the Economy, Stupid! Explaining the Electoral Success of the German Right-Wing Populist AfD.” In: CIS Working Paper (94).

Scrinzi, Francesca (2017): "Gender and Women in the Front National Discourse and Policy: From 'Mothers of the Nation' to 'Working Mothers'?" In: New Formations 91 (91), pp. 87-101.

Spierings, Niels/Zaslove, Andrej/Mügge, Liza M. et al. (2015): "Gender and Populist Radical-Right Politics. An Introduction.” In: Patterns of Prejudice 49 (1-2), pp. 3-15.

Thelandersson, Fredrika (2014): "A Less Toxic Feminism: Can the Internet Solve the ageold Question of How to Put Intersectional Theory into Practice?" In: Feminist Media Studies 14 (3), pp. 527-530.

Wemple, Erica (2019): President Trump. Our Fakenews Ambassador. Online: www.washingtonpost.com/opinions/2019/03/19/alongside-brazilianpresident-trump-hails-fake-news-bond/, 03.10.2019.

Wichterich, Christa (2000): The Globalized Woman: Reports from a Future of Inequality. North Geelong: Spinifex Press.

Wizorek, Anne (2014): Weil ein Aufschrei nicht reicht. Für einen Feminismus von Heute. Frankfurt a. M.: Fischer.

Wodak, Ruth (2015): The Politics of Fear. What Right-Wing Populist Discourses Mean. London: Sage.

Zick, Andreas/Küpper, Beate/Berghan, Wilhelm (2019): Verlorene Mitte - Feindselige Zustände. Rechtsextreme Einstellungen in Deutschland 2018/19. Berlin: Dietz. 